\title{
Antiamerikanisme og ensidighed i Europa
}

\section{Bent Blüdnikow}

\section{De stærke antiamerikanske følelser i Europa skyldes mere end foragten for præsident George W. Bush. De har dybe historiske rødder og afspejler europæernes afmagt og svaghed i for- hold til USA}

De fleste kan nok huske de negative europæiske følelser, der rettedes mod præsident Ronald Reagan. Han blev kaldt dum, en b-skuespiller og bl.a. en gal hund. Det var historisk set forklarligt, at han var så upopulær på det europæiske kontinent, for vi stod midt i en farlig periode under Den Kolde Krig, og USA strammede politisk kravene og retorikken over for Sovjetunionen.

Europa brød sig ikke om, at Sovjetunionen blev kaldt "Ondskabens Imperium", og selvom dissidenterne i Sovjetunionen og $\emptyset_{\text {steuropa tiljub- }}$ lede USA og Ronald Reagan, så syntes brede kredse i Europa, at det var ubehageligt, at USA - set med europæiske øjne - var konfrontationssøgende og absolutistisk i sit sprogbrug. Måske fordi Europa ikke ønskede at blive inddraget yderligere i konflikten, fremmanede man et verdensbillede af to lige uforsonlige fjender, hvor bl.a. mange danskere kunne illudere, at vi holdt os uden for opgøret. Denne mentale linedanse fik kredse i Europa - herunder Danmark - til at tegne et billede af den amerikanske præsident som aggressiv, ubegavet og simpel.

Historiens gang har ændret alt dette. Kommunismens sammenbrud gav Ronald Reagans politik et helt andet eftermæle, og ved hans død blev han prist - også i danske medier - som en af de store præsidenter. I den sidste vurdering af perioden skrevet af den førende koldkrigs-forsker John Lewish Gaddis The Cold War. A New History (2005), står der at Reagan var "en af de mest kompe- 
tente politikere som USA havde haft og en af de skarpeste strateger overhovedet".

Meget af retorikken mod præsident Ronald Reagan kan genfindes i den temmelig unisone europæiske beskrivelse af præsident George W. Bush. Mange europæiske stemmer har ligeledes beskrevet ham som absolutistisk, aggressiv, endimensional og dum. Man behøver ikke at lede længe i europæisk og dansk presse for at finde mængder af udtalelser og artikler, der fremstiller USA og Bush-regeringen med en række yderst ubehagelige tillægsord.

Der synes at være noget provokerende ved George Bushs ærkeamerikanske udseende og retorik, men den negative indstilling rammer ikke blot præsidenten, men er rettet mod hans administration, hans intellektuelle venner og sandelig også hele nationen. Det er måske ikke underligt, idet situationen internationalt nu på flere måder minder om de varmeste dage under Den Kolde Krig. Også nu er USA involveret i et opgør mod kræfter, som bliver kaldt onde, og hvor den amerikanske præsident går ind for offensive metoder for at bekæmpe fjenden.

\section{Dum som en dør}

Den hårde tone over for Bush-regeringen vandt snart fodfæste i Europa efter en kort periode med sympati for USA efter terrorangrebet på USA i september 2001. Den ameri- kanske filminstruktør og forfatter Michael Moore scorede en overvældende europæisk succes med sin bestsellerbog Stupid White Men med præsident Bush i en stjernerolle.

Moore fandt et europæisk publikum, der mente, at præsidentens manglende intelligens var forklaringen på den amerikanske politik. Og sandelig om hans film ikke også fik de fineste europæiske priser. I Frankrig blev antiamerikanske bøger bestsellere, og gamle venstreorienterede intellektuelle, som fx Noam Chomsky, der altid havde anset USA for at være menneskehedens fjende, blev nye feterede superstjerner.

Foruden udenlandske røster var der også mange danske stemmer, der blandede sig i koret. Digteren Henrik Nordbrandt sagde om George W. Bush i Berlingske Tidende, at han var "dum som en dør" (24.10.2002) og i Information skrev han, at $\varnothing$ kologien har det skidt og mennesket står i mudder til livet: "Det svarer til, at man stod i et lille kosteskab og bare ville æde og skide det samme sted. Så kommer lortet højere og højere, og alligevel bliver man ved. Det er jo den situation, mennesket står i. Hvem som helst kan se det, selv George W. Bush, nej måske lige med undtagelse af ham." (4.8 2001).

Digteren Klaus Rifbjerg bidrog ved at beskrive Bush nærmest som en analfabet med et ordforråd som i en hjælpeklasse og betegnede ham som en primitiv hulemand. Det 
skrev han i bogen Tidsmaskinen (2002), og han har senere skrevet i Information, at det står enhver frit for at afgøre, om Bush er evnesvag eller sindssyg (8.8 2002). Ifølge Rifbjerg tilbeder denne åndelige undermåler ligefrem krigen: "Og nu kommer så den ny krig, uønsket af mange, men tilbedt af dem, der mener, at de er med på noderne: Anders Fogh Rasmussen hånd i hånd med George $\mathrm{W}$. Bush." (Politiken 23.2.2003).

Politikens chefredaktør Tøger Seidenfaden hoppede på vognen med bemærkningen: "Det kan godt være, at amerikanerne er glade for Bush, for han er lidt dummere, end de selv er." (21.11.2002). Observationen faldt i Danmarks Radios TV-udsendelse Debatten.

Senest har filminstruktør Lars von Trier i 2005 bidraget til den politiske analyse ved at kalde Bush for et "røvhul": "Jeg er ikke amerikaner. Jeg kan ikke stemme, jeg kan bare sidde langt væk i en nation under dårlig indflydelse. Bush er et 'asshole', men lad os ikke tale om ham. Amerika sidder på verden, derfor laver jeg film om USA, er det så underligt?" (Berlingske Tidende 22.05. 2005)

\section{Nationalistisk og selvtilstrækkelig}

Lad mig nævne et enkelt eksempel lidt grundigere, nemlig redaktør Torben Krogh, der i forrige nummer af Udenrigs (3.2005) har skrevet en artikel med titlen "Præsident
Bushs politiske orkan”.

Her gennemgår han en række af de mest negative ting, der er sket i Amerika i de senere år under Bushregeringens periode. Han nævner orkanen Katarina. "Harmen samlede sig ikke mindst om præsident George W. Bush. Han og hans regering undervurderede i første omgang helt og aldeles, hvad der var sket”, skrev han.

Torben Krogh nævner derefter alle de andre fatale fejl hos regeringen: De sociale skel er blevet forøget under Bushs regeringsperiode. Børnedødeligheden er vokset under præsident Bush. Fattigdommen er ligeledes blevet større. Der tegnes et billede af en præsident med en "autoritet helt i bund" og med manglende "lederevner". USA fik "ridser i lakken", skriver Krogh, fordi det måtte modtage hjælpe fra Europa efter Katarina. Og så optegner Torben Krogh et rædselsscenario for fremtiden, der ifølge Udenrigs'redaktør meget vel kan blive endnu mere "nationalistisk og selvtilstrækkelig" med Bush ved roret. Regeringen vil ikke indgå forpligtende internationale aftaler, der på nogen måde begrænser dets egen handlefrihed, skriver Krogh og med bemærkningen, at Bush-regeringens udviser "magtens arrogance" og mangel på ydmyghed, fuldender redaktøren den fuldstændige nedsabling af USA's regering uden at nævne en eneste positiv ting.

Meget af det som Torben Krogh 
og andre kritikere har fremhævet er jo ikke nødvendigvis helt forkert, men ved udelukkende at fokusere på de negative forhold under Bushregeringen får man alligevel troldspejlets forvrængede billede.

Man behøver ikke at læse meget i konservative tidsskrifter som National Review, Weekly Standard, Wall Street Journal og andre medier for at se et helt andet billede af udviklingen i USA. Her lægges der vægt på, at Bush-regeringen har skabt et usædvanligt højt bruttonationalprodukt, der klart overhaler det europæiske. Denne økonomiske udvikling har løftet mange fra underklassen op i middelstanden.

Desuden har den ekspanderende $\varnothing$ konomi og de mange nye arbejdspladser betydet, at mange immigranter har fundet arbejde og er blevet integreret i det amerikanske samfund. Millioner af immigranter er legalt og illegalt kommet til USA, og mange af dem har klaret sig takket være den ekspanderende økonomi - selvom mange af dem også overlever på minimumslønninger.

Og endelig er det USA, der har drevet verdensøkonomien frem i de senere år. Den gode økonomiske udvikling er ikke kun Bush-regeringens skyld, men kan tilskrives generelle konjunkturer, men det er nu heller ikke kun Bush-regeringens skyld, hvis der er forhøjet børnedødelighed.

$\varnothing$ konomen Irwin M. Stelzer skriver i Weekly Standard 15.8 2005: "Da
Bill Clinton forlod præsidentposten var godt 138 millioner amerikanere i arbejde. Reel kompensation - løn samt benefits - voksede med 2,8\% om året, da Bush blev præsident. I første kvartal af 2005 voksede det med imponerende 3,9\%. I det forløbne år har økonomien tilføjet 2,4 millioner jobs.(...)". Eller læs professor Peter Kurrild-Klitgaard, der i flere artikler har påvist, at det går rigtig godt i USA, og at bl.a. levestandarden er $30 \%$ højere i USA end i Europa (Berlingske Tidende 16.07 2005). Med henblik på børnedødeligheden er jeg afskåret fra at kommentere Torben Kroghs interessante tal, da han ikke opgiver nogen kilde. Men muligvis har han ret.

Det fremgår også af Torben Kroghs artikel, at "magtens arrogance" har fået USA's regering til at afvise internationale forpligtelser. Hvis man lytter til den engelske historiker Niall Ferguson, hvis udfordrende bøger som fx Colossus er en stor læseoplevelse, tegner der sig et andet billede. Han siger i Politiken i et interview med Adam Holm: "Sandheden er, at USA arbejder hårdt $\mathrm{og}$ loyalt inden for rammerne af internationale fora som Verdensbanken og Verdenshandelsorganisationen WTO. Og de små krige i Afghanistan og Irak er mindre vigtige for den amerikanske regering end det at overholde sine løfter til allierede og interessepartnere rundt om på kloden. Vi har at gøre med et samvittighedsfuldt imperium, også selv 
om venstrefløjen og alle mulige andre USA-modstandere prøver at tegne det modsatte billede." (Politiken 24.092005 ).

Jeg vil ikke påstå, at Torben Krogh har helt uret, og Ferguson helt ret, men det er ærgerligt, at tidsskriftet Udenrigs kun tegner det negative billede. Det er ikke pluralisme, for i de senere år har der ikke været artikler i Udenrigs, der kunne rette op på Kroghs mørke billede. Torben Krogh beskriver et aggressivt USA, der kører sin egen linje ud fra devisen "dem der ikke er med os er imod os".

Andre analytikere tegner et langt mere nuanceret billede. En af dem er John Lewis Gaddis, der af mange betegnes som Den Kolde Krigs største historiker. Gaddis skriver også om vor samtidspolitik, og han har i bogen Surprise, Security and the American Experience (2003) skrevet om amerikansk sikkerhedspolitik. Heri understreger han, at der går en lige linje fra Clinton-regeringens politik og over i Bush-regeringens.

Der er ikke blot tale om en kontinuitet, nej han skriver ligefrem, at Bush-regeringen i sin 2002 plan The National Strategy Security of the United States of America er mere multilateral end forgængeren Clinton: "Bushs mål understreger forsvar, bibeholde og udvide freden, Clinton synes kun at forudsætte fred. Bush påberåber sig samarbejde mellem stormagterne; Clinton brugte aldrig de udtryk. Bush understreger, at man må op- muntre frie og åbne samfund i alle kontinenter, Clinton nøjedes med at være tilfreds med at "fremme" demokrati og menneskerettigheder i "udlandet". Selv i disse indledende linjer er Bushs plan mere magtfuld, mere omhyggelig formuleret og uventet mere multilateral end dens forgængere".

Nu er Gaddis slet ikke republikaner, men snarere demokrat, men hans analyse er gennemgående positiv over for Bush-regeringens udenrigspolitik. Han skriver videre, at tendensen til at undervurdere Bush har været specielt fremherskende blandt amerikanske og europæiske akademikere: "Det har uden tvivl noget at gøre med den dominerende venstreorienterede politiske holdning i disse kredse."

Man kan fremdrage en hoben kommentatorer, der er er mindst lige så kritiske som Torben Krogh over for USA, men man kan sandelig også fremdrage mange, der roser Bush-regeringen og dens gerninger. Når Gaddis er lidt af et sandhedsvidne, er det fordi hans forskning er blevet rost til skyerne af samtlige anmeldere, og at han er hævet over enhver mistanke for at gå Bush-regeringens ærinde.

\section{Hæng Bush}

Vi ved fra opinionsundersøgelser, at de USA-fjendtlige holdninger har godt fat i de europæiske befolkninger. En undersøgelse fra 2002 viste, 
at en bred majoritet i Frankrig, Japan og Tyskland bedømte den amerikanske politik negativt. Undersøgelsen var foretaget af det amerikanske udenrigsministerium. I en opinionsundersøgelse fra oktober 2003 svarede en række udvalgte nationaliteter på hvilke lande, der truede verdensfreden. Hele $59 \%$ pegede på Israel og $53 \%$ pegede på USA. De lå som henholdsvis nr. 1 og 4 på listen, og USA blev kun overhalet af Iran og Nordkorea. Der var udvalgt 7515 europæere til at deltage i undersøgelsen.

En undersøgelse fra PEW Research Center fra januar 2005 konkluderede, at holdningen til USA og Bushregeringen vedblev at synke, og de store lande i Europa, hvor undersøgelsen koncentrerede sig, havde katastrofalt lave popularitetstal. Undersøgelsens forfattere skrev i deres konklusion: "De antiamerikanske følelser går dybere og bredere end på noget tidspunkt i moderne historie.

Det er mest akut i den muslimske verden, men den dækker hele globen; fra Europa til Asien, fra Sydamerika til Afrika. Og selv om meget af denne antipati er rettet direkte mod præsident Bush og hans politik, specielt krigen i Irak, så viser disse stadig hårdere holdninger mere end blot tommelfingrene nedad for dem, der lige nu sidder i Det Hvide Hus."

Senest har tidsskriftet Foreign Policy (februar 2006) trykt en undersøgel- se, der bekræfter den negative europæiske indstilling: Faktisk er USA's upopularitet større end nogensinde i Europa, og kun polakkerne har en vis sympati for landet.

De antiamerikanske følelser gik ikke ubemærket hen over amerikanske medier og kommentatorer. Et typisk eksempel er magasinet Time fra august 2003, der indeholdt følgende malende beskrivelse: "Velkommen til den mærkelige verden af transatlantiske forbindelser, som på det seneste synes at være mere påvirket af lærebøger om dysfunktionelle familier end af manualer i diplomati. I disse dage synes det som om, at alle dele af det europæiske kontinent er grebet af frygt og foragt for USA. Tusindvis vandrer gennem Europas hovedstæder for at fordømme den USA-ledede krig i Irak og dukkeudgaver af George W. Bush bliver klynget op og brændt. Men den stærke opposition mod krigen er bare det nyeste element i de antiamerikanske følelser. Man kan spørge en hvilken som helst europæer, og man får ørerne tudet fulde af USA's kulturelle og økonomiske dominans, amerikansk arrogance, amerikansk snæversynethed, amerikansk blindhed over for global opvarmning, fattigdom i verden og palæstinensernes skæbne."

I 2002 skrev Salman Rushdie i sit essay "Anti-Americanism has taken the world by storm" i Guardian: "Enhver der har besøgt Storbritannien og Europa eller har fulgt de of- 
fentlige samtaler dér i de sidste fem måneder, er blevet slået, ja endda chokeret, over dybden af antiamerikanske følelser i store dele af befolkningen og i nyhedsmedierne. Den vestlige antiamerikanisme er et meget mere pirreligt fænomen end dets arabiske udgave og - mærkeligt nok - meget mere personlig."

\section{Verdens boksehold}

Den franske filosof Bernard-Henri Levy har lige udgivet sin nye bog American Vertigo: Traveling America in the Footsteps of Tocqueville. Ved udsendelsen i februar 2006 blev han interviewet til New York Sun (31. januar 2006) og sagde bl.a.: "Amerika bliver ofte dæmoniseret i udlandet. Den bedste måde at svare på den slags dæmonisering er at vise, at USA er en stor nation, der dog også laver fejltagelser - men det er en stor nation, også hvis vi tager disse fejl med. Hvad der forbavser mig er, at landet er i langt mindre krise, end man får indtrykket af i udlandet. Demokratiet er langt sundere end det antages i udlandet. Antiamerikanisme er en pest, og sig blot hvad du vil om USA, men det står stadig for sandhed og retfærdighed".

I sin bog Longitude and Attitudes skriver New York Times-kommentatoren Thomas Friedmann: "Siden Den Kolde Krigs slutning har anti-amerikanismen overtaget førertrøjen fra fodbold som verdens mest populære sport... Der er en generel opfattelse i intellektuelle kredse, at USA har skylden for alt, hvad der går galt, og mange amerikanske intellektuelle spiller med og accepterer, at USA har rollen som verdens boksebold. Og når du nægter at acceptere dette i blandet selskab, er det som om du har slået en ordentlig prut ved et cocktail party - folk ser mærkeligt på dig og begynder at gå baglæns”.

Man kan hævde, som mange da også gør, at stemningen i Europa ikke er antiamerikansk, men blot kritisk over for Bush og hans regering. Men i så tilfælde må vi konkludere, at den heller ikke var antiamerikansk under præsident Ronald Reagan, men blot vendt mod hans person. Men det var ikke virkeligheden, for bag stormløbet på den "ubegavede" Reagan lå en dyb antipati og frygt for hans direkte politik over for Sovjetunionen.

Den konservative kommentator og samfundsforsker Robert Kagan, ham med "USA er fra Mars og Europa fra Venus", skrev i tidsskriftet Policy Review (juni-juli 2002), at antiamerikanismen ikke er et "George Bush-problem”, men hovedsagelig skyldes europæisk misundelse over for amerikansk militær styrke og mod.

Det vil da også være alt for ahistorisk at tro, at det blot er uviljen mod den ærkeamerikanske præsident Bush, der udløser denne vrede, for mange andre tidligere præsidenter har fået samme harme og bitterhed 
rettet mod sig. Den amerikanske forsker Judy Colp Rubin skriver i artiklen "Is Bush Really Responsible for Anti-Americanism Around the World" på websiden "History News Network", at også Thomas Jefferson og Benjamin Franklin blev udsat for dyb europæisk hån og forbitrelse.

\section{Den daglige nyhedsstrøm}

Billedet af et farligt, amoralsk og aggressivt USA kommer til udtryk ikke blot gennem enkelte rabiate vurderinger og artikler, men ligger som en understrøm i den europæiske nyhedsdækning. Der er ikke en dag, hvor nye skandaler og nye afsløringer ikke tegner et billede at et famlende og aggressivt USA med en inkompetent regering, der styres af ubehagelige mørkemænd i form af de såkaldt neo-konservative. I dansk presse er der i årevis tegnet et ensidigt billede af disse neo-konservative som hovedsagelig jødiske intellektuelle, der mere styres af hensyn til Israel end hensyn til deres eget hjemland.

Således beskrev Lars Erslev Andersen tidligere sikkerhedsrådgiver Richard Perle som "Mørkets fyrste", der angiveligt skulle havde sæde i bestyrelsen for den israelske avis $J e^{-}$ rusalem Post (Lars Erslev Andersens artikel i antologien USA/EUROPA fjender i Fallesskab, red.: Clement Behrendt Kjersgaard). Det var imidlertid ikke rigtigt, idet Perle ikke har siddet $\mathrm{i}$ avisens bestyrelse, men det passede godt ind i den almene mytedannelse. Erslev Andersen tegnede, som andre danske kommentatorer i denne periode, et billede af et internationalt netværk af jødiske intellektuelle, der så at sige styrede USA's udenrigspolitik. Ikke noget kønt indslag i debatten.

Disse neo-konservative, der dækker et bredt felt af spændende intellektuelle, har også i bladet Udenrigs fået med grovfilen. Bladet har trykt en artikel af Christoph Bertram i 2003 nr. 2 med en særdeles hårdhændet nedrakning af denne brede gruppe. Artiklen havde titlen "Svar til Robert Kagan", men Udenrigs har ikke en eneste gang ladet en af bevægelsens egne folk forklare sig eller svare på Bertrams kritik. Det ville da ellers have været af interesse for læserne, nu da de var blevet skarpt kritiseret.

Europæisk offentlighed bombarderes med negative informationer om USA. Og en del af det er rigtigt. Der begås fejl, og George Bush og hans regering har truffet en række uheldige beslutninger. Det er dog ikke hele sandheden, men informationsstrømmen i fx Danmark baserer sig for $80 \%$ vedkommende af artikler fra New York Times og Washington Post. Der er tale om oppositionsaviser, og hvis man plukker de mest sensationelle og aggressive artikler og kommentarer ud, så får man ikke et retfærdigt og nuanceret billede. Men det er hvad der sker, og de mange andre aviser citeres sjældent. 
Man kan indvende, at de to anførte aviser også har borgerlige kommentatorer. Ganske rigtigt, men i danske aviser citeres de kun undtagelsesvist. Ser man fx på dækningen i dagbladet Politiken er kommentatorerne plukket, så de kun bekræfter det negative billede, som avisen i forvejen tegner med dets egen nyhedsdækning. Det er ikke pluralisme, ja det end ikke nærmer sig. Men hvis man ikke kender til den brede debat i USA og ikke ved, at der er mange andre opfattelse end dem, som udvælges til det europæiske marked, så kan man ikke vide, at der ikke informeres pluralistisk.

Billedet af USA er dog blevet nuanceret i det sidste års tid. Det er internettet, der har gjort sin virkning, og pludselig dukker konservative kommentatorer som William Kristol, Norman Podhoretz, Charles Krauthammer og andre sjældne fugle op i debatten. De er dog stadig marginale stemmer, og ofte får de af dansk presse prædikater som "stærkt højreorienterede" eller "kontroversielle" hæftet på sig, inden læserne får lov til at læse deres ord.

\section{Den historiske dybde}

Nyhedsdækningen og aviserne øvrige dækning af USA lider af et andet principielt problem, som jeg vil kalde ahistorisme. Man har ikke historisk dybde i dækningen og kan derfor ikke drage sammenligninger el- ler forstå den dybere mening med de magtpolitiske tiltag. De fejl, som USA har begået, får uden denne historiske dybde en unik karakter, som det værste, der er sket i menneskehedens historie. Det synes ikke at indgå i journalisternes bevidsthed, at USA i de mange krige, det har ført, har begået handlinger, der er langt værre end dem George W. Bush har haft det øverste ansvar for.

Fangeovergrebene i Irak og Afghanistan er brud på menneskerettighederne, men de er relativt små sager, hvis vi ser på de massakrer på krigsfanger, som amerikanske og engelske soldater begik over for tyske og japanske fanger under Anden Verdenskrig. I dag følges der juridisk op på forbrydelserne, hvad man som regel ikke gjorde dengang.

De strategiske fejltagelser i Irak, som USA bebrejdes så stærkt, er det rene vand, hvis vi ser på hvad præsident Roosevelt og præsident Truman begik af brølere under Anden Verdenskrig og Koreakrigen. Man begik elementære strategiske fejl med store konsekvenser til følge, og man svigtede befolkningsgrupper med fatale følger i en lang række konflikter som fx Kina i 1920'erne og 1930'erne og Sydamerika i 1950'erne og 1960'erne.

Jeg nævner alt dette ikke for at skildre USA som et ond nation, men netop for at understrege, at supermagten USA, der handler aktivt i verden, også ustandselig begår fejl. Nationer, der ikke handler aktivt, 
som fx Sverige, er ikke udsat for den slags fejl, men hytter blot sit eget skind. Men medierne synes at glemme, at de fejl Bush-regeringen begår relativt set er små i forhold til, hvad andre præsidenter har haft ansvar for.

Der er også en dybere pointe med dette tilbageblik. Europæerne ved jo godt, at USA dels for at sikre sig selv og dels vitterlig for at styrke demokratiet og frelse mennesker i bl.a. Europa, som det er sket gang efter gang i det 20. århundrede, er at foretrække frem for andre nationer som verdens leder. Flere af de europæiske opinionsundersøgelser peger da også på, at på trods af den stærke kritik af USA, så er der alligevel en forståelse for, at denne stormagt dog er af den godartede slags.

\section{Forklaringerne}

Men hvad er så årsagerne til denne antiamerikanske holdning i Europa?

Går vi tilbage $\mathrm{i}$ historien er det klart, at der lige siden 1700-tallet har hersket en foragt for det amerikanske samfund, som europæerne anså for at være plumt, primitivt og styret af profit. Det er også et gennemgående træk, at det amerikanske samfund har været symbolet på modernitet og massekultur. Professor i klassisk historie og kommentator Victor Davis Hansson skriver i artiklen: "Why do they Hate US" (oktober 2004 National Review): "Hadet til USA er ikke nyt. Og det har heller ikke meget at gøre med George W. Bushs upopularitet. I stedet bør man se på psykologiske dybtliggende følelser som misundelse, forbehold og selvhad for at forklare, hvorfor Europas elite fordømmer amerikanerne".

Salman Rushdie skrev i den tidligere citerede artikel fra Guardian: "Hvad USA bliver anklaget for - intellektuel lukkethed, fordomsfuldhed og uvidenhed - er det som anklagerne ser, når de kigger sig i spejlet". Robert Kagan har i flere artikler og i bogen Paradiset og magten peget på, at det europæiske kontinent er præget af mangel på militær styrke, svag økonomisk fremdrift og forvirring om kontinentets kulturelle og nationale identitet. Som en modpol til USA opstiller europæerne et billede af et Europa, der går ind for samarbejde, internationale traktater, menneskerettigheder, fred og samtale og et Bush-USA, der står for alt det modsatte.

Hvis man vil pege på danske eksempler, så kan vi citere Mogens Lykketoft fra hans korte tid som udenrigsminister, da han på et møde i Udenrigspolitisk Selskab tegnede et billede af Europa som et humant og progressivt modbillede til USA: "EU har mange fælles synspunkter, holdninger og værdier, som vi i stigende grad vil søge at præge det internationale samfund med, og som er i modsætning til synspunkterne hos den nye amerikanske regering (...) EU er reelt vo- 
res slagkraftige, progressive platform i kamp for global menneskelig udvikling. Det blev illustreret, da det i sidste måned lykkedes EU at formidle et globalt kompromis mellem 179 lande, der fastholder det fundamentale i Kyoto-protokollen - men uden USA". Der blev derefter tegnet et billede af et USA, der svarede temmelig nøje til det, som Torben Krogh portrætterede. Et egoistisk USA, der ikke ønskede at opfylde internationale forpligtelser.

Kritikken - også den meget barske - er ikke et venstrefløjsfænomen, men kan også findes på højrefløjen. Jeg kunne pege på en leder fra Berlingske Tidende, hvor den negative opfattelse af USA og den positive af Europa lyder således: "Hendes (udenrigsminister Rice) erklæring viser, hvor hårdt ramt amerikanerne stadig er efter terrorangrebene $\mathrm{i}$ 2001. Den viser forskellen på amerikansk og europæisk reaktion på terror. Hvor amerikanerne tror, at de bekæmper terror ved at bøje og overtræde menneskerettigheder, tror europæerne på, at respekt for menneskets rettigheder er det eneste langtidsholdbare forsvar mod terror." (Berlingske Tidende 7.12 2005).

Lederen var skrevet på baggrund af mistanke om CIA-flyvninger af terrormistænkte over Europa. Den dag i dag er der ikke fremkommet bevis på, at det er sket, men blot mistanken var nok til generelle anklager mod USA. I øvrigt må det her som alle andre steder understreges, at selvfølgelig skal enhver overtrædelse af fx. menneskerettigheder kritiseres, og intet sted bliver de kritiseret så stærkt som i USA selv.

\section{Kommunismens fald}

En af dem, der har forsøgt at give en bred forklaring på anti-amerikanismen, er professor Russell A. Berman i sin bog Anti-Americanism in Europe. A Cultural problem (2005). Berman peger på, at kommunismens fald betød, at Europa ikke længere behøvede amerikansk beskyttelse, og at antiamerikanske holdninger, der altid havde eksisteret, derfor blev mere uhæmmede. Denne antipati blev styrket af det forhold, at USA blev den eneste tilbageværende supermagt.

Han peger på, at Europa behøvede antiamerikanismen i tiden efter kommunismens fald for at styrke sin egen identitet. Europas politiske overklasse, skriver Berman, var fuldkommen klar over den vulgaritet, som antiamerikanismen repræsenterer. Men intelligentsiaen besluttede sig til at løbe med og ikke sige fra over for den massive antiamerikanisme, der har skildret amerikanerne som krigsliderlige og Bush som ikke bare dum, men også som kristen fundamentalist - lige så slem som Irans afdøde overhoved Khomeini.

Bermans holdning er, at man også skal finde rødderne til antiamerikanismen i kulturelle faktorer. Ameri- 
ka som den førende magt i verden, der angiver den kulturelle førertrøje inden for musik, film, IT og så meget andet, er en stadig provokation for det Europa, der har svært ved at finde sine egne ben både politisk og kulturelt. Derfor udlægges USA som primitivt, voldeligt, fundamentalistisk, dumt, superliberalistisk, aggressivt og domineret af jødiske intellektuelle. Europæerne kompenserer så at sige for deres eget mindreværd ved at fremmane et vulgariseret billede af USA. I sin kerne ser Berman antiamerikanismens grundstof som antipatien mod demokratisk kapitalisme, som USA mere end nogen anden nation symboliserer. Derfor, skriver Berman, har antipatien ikke meget at gøre med, hvem der lige er præsident, eller hvilke konflikter USA lige netop nu er involveret i.

En anden skribent, der har forsøgt er gennemtænke den "besættelse", som antiamerikanismen er for Europa, er franskmanden Jean François Revel. I hans bog fra 2003 AntiAmericanism gør han sig til talsmand for det synspunkt, at USA ses som kapitalismens højborg. Globaliseringen er den seneste udvikling af kapitalismen, og det ses som en amerikanisering af verden. Der er stadig, selvom venstrefløjen ideologisk set er afgået ved døden, en dyb væmmelse mod liberalisme og kapitalisme. Denne afstandstagen fra den grådighed og egoisme, som forbindes med liberalisme og kapitalisme, symboliseres ved Amerika.
Også Thomas Friedman skriver i sin bog Longitude and Attitudes, at globaliseringen ses som en amerikanisering, og at dette er en af årsagerne til antipatien mod USA.

I den netop udkomne bog Understanding Anti-Americanism (2005) er der en lang række bidrag, der forsøger historisk og kulturelt at forstå rødderne til hadet til USA. Antologien er redigeret af Poul Hollander, der i årtier har været en af de fineste Sovjet-historikere. De historisk betingede årsager til fjendskabet over for USA er i sig selv interessante, men Hollander og hans stab peger på, at fjendskabet alligevel har radikaliseret sig. Hollander peger på 4 afgørende årsager til antiamerikanismens vækst i disse år:

1. Efter kommunismens fald er USA den eneste supermagt på jorden, og det er derfor ikke mærkeligt, at den tiltrækker kritik og aggression.

2. USA's anvendelse af militær magt og politisk aktivisme tiltrækker altid ekstra kritik og vrede. De seneste års magtanvendelse i flere områder af verden har forøget den kritiske reaktion. Den negative reaktion på USA aktivisme er tæt forbundet med den i forvejen negative opfattelse af det amerikanske samfundssystem. 3. Præsident Bushs person og politik: Hans cowboy-stil og angivelige sort-hvide måde at se og tale om verden har medført vrede, som yderligere får næring af hans stærke patriotisme.

4. Globaliseringen er et af de stærke 
elementer i radikaliseringen af antiamerikanismen. Hollander mener $\mathrm{dog}$, at der er tale om gammelt antikapitalistisk had, blot i nye gevandter.

\section{Manglende selvransagelse}

USA må finde sig i kritik - og gør det da heldigvis også. Nationen har afgørende ansvar for verdens tilstand og tager da også denne opgave alvorligt. Niall Ferguson har sagt, at uanset fejlene er det en lykke, at det er USA, der er verdens supermagt og ikke Frankrig eller Kina.

Hvad vi i Danmark må være opmærksomme på er, at informationerne i Europa ikke altid er udtryk for pluralisme. Vi får serveret en temmelig snæver informationsstrøm, der desværre har en tendens til at bekræfte europæiske fordomme. Der er en manglende selvransagelse i Europa, der har meget let ved at se fejlene hos amerikanerne, men har sværere ved at se svaghederne hos sig selv.

Det er en oplagt opgave for europæiske og herunder danske medier at tage udfordringen op og forsøge at undgå fordommene om USA. Det betyder ikke at mindske kritikken, men at få flere stemmer ind i koret og søge andre holdninger og reel pluralisme.

Bent Blüdnikow er cand.mag. og journalist. 